\title{
THE DIFFERENCE OF SODIUM INTAKE, PHYSICAL ACTIVITIES AND PSYCHOLOGICAL PROBLEMS OF PATIENTS SUFFERING FROM HYPERTENSION IN RURAL AND URBAN AREAS
}

\author{
Heny Suseani Pangastuti ${ }^{1 *}$, Melyza Perdana ${ }^{2}$, Dewi Agustina Wati ${ }^{3}$, Hatifah Ihsanda Tien \\ Melati $^{4}$, Rizki latifah ${ }^{5}$ \\ ${ }^{1,2}$ Department of Medical Surgical Nursing, Faculty of Medicine, Public Health and Nursing, \\ Universitas Gadjah Mada \\ ${ }^{3,4,5}$ School of Nursing, Faculty of Medicine, Public Health and Nursing, Universitas Gadjah \\ Mada \\ Email*: heny_pangastuti@ugm.ac.id
}

\begin{abstract}
Introduction: The patients suffering from hypertension require treatment to prevent the complications by performing both pharmacological and non-pharmacological hypertension management. This research aims at revealing the difference of sodium intake, physical activities, and psychological problems in patients suffering from hypertension in rural and urban areas. Methods: This descriptive-quantitative research employs a cross sectional design. The research was conducted at Gondokusuman Community Health Center 1 as the representation from the urban areas and Cangkringan Community Health Center as the representation from the rural areas. There were 81 patients from rural areas and 74 from urban areas. Data were collected using a consecutive sampling technique with Semi Quantitative Food Frequency Questionnaire (SQ-FFQ), Global Physical Activity Questionnaire (GPAQ) and Depression, Anxiety, Stress Scale 42 (DASS 42). The data analysis was conducted using both chi-square test and independent t-test. Results: The result of independent t-test for sodium intake was at $p=0.669$ ( $p>$ 0.005). The result of analysis using chi-square test for physical activity was at $p=0.000(p<0.05)$. The result of analysis using chi-square test for depression level is at $p=0.964(p>0.05)$, anxiety level at $p=$ $0.005(p<0.05)$ and stress level at $p=0.846$ ( $p>0.05)$. Conclusions: There are some differences in physical activities and anxiety levels in patients suffering from hypertension in rural and urban areas.
\end{abstract}

Keywords: hypertension, sodium intake, physical activity, psychosocial problem, depression, anxiety, stress, rural, urban

\section{INTRODUCTION}

Hypertension is one problem commonly found in both developed and developing countries which continuously increases each year in various regions, including Indonesia. In the world, in 2010, $31,1 \%$ adults had hypertension. (Milis, et al, 2016). Based on the Basic Health Research (Riskesdas) result of 2013 (Ministry of Health, 2013), the incidence of hypertension in Indonesia is $25.8 \%$ with DIY Province ranks the $3 \mathrm{rd}$ with a figure of $12.8 \%$ and far above the average of Indonesian people (Ministry of Health of the Republic of Indonesia, 2014).

In global era, many people have unhealthy life style that can be a risk factor for suffering hypertension. This effect can be found in urban area. Kumar et al (2013) found that in India, hypertension in urban area is higher $(24,25 \%)$ than in rural area $(13,17 \%)$. In Indonesia, hypertension is higher in urban area than in rural area (Aisyiyah, 2009). Based on Basic Health Research (Riskesdas) result of 2013 (Ministry of Health, 2013), the prevalence of hypertension in rural area is 5,6\% and ini urban area $5,1 \%$. This is because the use of health facilities are low ini urban areas (Aizawa \& Helble, 2016).

Hypertension which is not immediately treated and controlled may be proceeded to become more severe hypertension level. The severe undiagnosed hypertension may increase the risk of lifethreatening complications, such as coronary heart disease, kidney failure and stroke (Ministry of Health, 2014). 
The hypertension complications
may be prevented with both pharmacological and non-pharmacological hypertension management. In patients suffering from hypertension level 1 may be suggested to have a healthy lifestyle for 4-6 months, such as weight loss, reduced salt intake, exercise, reduced alcohol consumption and stopped smoking. In addition, stress management should also be considered in conducting the nonpharmacological therapy in patients suffering from hypertension. If there is not any change within a particular period, the pharmacological therapy is then recommended (PERKI, 2015).

Hypertension patient have poor adherence in diet. Agrina et al (2011) found that $56,7 \%$ patient not adherence in diet with sodium restriction. This fact can be a problems for suffering complication in hypertension. Primadita (2009) and Furkaniaty (2009) found that the sodium intake is related with hypertension. Yulia \& Rusli (2015) found that mean of sodium exresion in rural community is higher than in urban area.

The research conducted in 5 major cities in Indonesia shows that the physical activity of urban communities tends to be low (Khusun et al., 2016). It is similar with that found in the Special Region of Yogyakarta showing that the underactive physical activity proportion in urban areas is higher $(23.2 \%)$ than that in rural areas (16.1\%).

Islamia (2012) states that people living in urban areas have more psychological and social pressures than those living in rural areas. However, people living in urban areas have a higher welfare level than those in rural areas. The other psychological problems may be experienced by the patients suffering from hypertension are depression and anxiety. Xue et al. (2016) state that $12.8 \%$ of total research respondents has significant depression symptoms.

Based on the described background above, the researchers are interested in conducting a research. The purpose of this study was to identify the difference of sodium intake, physical activities and psychological problems of patients suffering from hypertension in rural and urban areas.

\section{METHODS}

This descriptive-quantitative research employs a cross sectional design, conducted in the special region of Yogyakarta (in Indonesia known as DIY), covering Argomulyo Village, Cangkringan District, Sleman Regency as a representation of rural areas as well as Demangan, Klitren and Baciro village/subdistrict, Gondokusuman district, Yogyakarta Regency Capital City as a representation of urban areas. Those areas included in the working areas of Cangkringan Community Health Center and Gondokusuman Community Health Center 1, within a period of May-June 2018.

The samples were taken using a consecutive sampling technique. The inclusion criteria are: 1) Patients suffering from hypertension based on the doctors' diagnoses from the related local Community Health Centers; 2) Patients with the age of $\geq 18$ years; 3) Permanent resident domicile in the under-study areas for $\geq 6$ months; 4) Patients are willing to be involved in this research. The exclusion criteria are: 1) Patients are in pregnancy condition or still breastfeeding their babies; 2) Patients with mental disorders; 3) patients suffering from stroke who experience weaknesses in their limbs. In this research, we used 155 respondents, 81 respondents are collected from rural area and 74 respondents from urban area.

The research variables are sodium intake, physical activities and psychological problems. The data are collected using the demographic data questionnaire, Semi Quantitative Food Frequency Questionnaire (SQ-FFQ), Global Physical Activity Questionnaire (GPAQ) and Depression, Anxiety, Stress Scale 42 (DASS 42) questionnaire which are valid and reliable.

Semi Quantitative Food Frequency Questionnaire (SQ-FFQ) is quationnaire for determinate the frequency of food consumption per day, week, month. This 
Table 1. The difference of sodium intake, physical activities and psychological problems of patients suffering from hypertension in rural and urban areas in Yogyakarta, within a period of May-June 2018

\begin{tabular}{|c|c|c|c|c|c|}
\hline \multirow[b]{2}{*}{ Variable } & \multicolumn{2}{|c|}{ RURAL (n=81) } & \multicolumn{2}{|c|}{ URBAN $(n=74)$} & \multirow[b]{2}{*}{ p-Vvalue } \\
\hline & $\mathrm{F}$ & $\%$ & $\mathrm{~F}$ & $\%$ & \\
\hline \multicolumn{6}{|l|}{ Sodium intake } \\
\hline Na Adequate $(\leq 2000 \mathrm{mg})$ & 55 & 68 & 53 & 71.6 & $0.669 *$ \\
\hline $\mathrm{Na}$ over $(>2000 \mathrm{mg})$ & 26 & 32 & 28.4 & 28.4 & \\
\hline \multicolumn{6}{|l|}{ Activity level } \\
\hline Light & 3 & 3.7 & 10 & 13.5 & $0.000 * *$ \\
\hline moderate & 32 & 40 & 44 & 59.5 & \\
\hline vigorous & 46 & 56.8 & 20 & 27 & \\
\hline \multicolumn{6}{|l|}{ depression level } \\
\hline Normal & 81 & 100 & 71 & 95.9 & $0.964 * *$ \\
\hline Mild & 0 & 0 & 2 & 2.7 & \\
\hline Moderate & 0 & 0 & 1 & 1.4 & \\
\hline Severe & 0 & 0 & 0 & 0 & \\
\hline Very severe & 0 & 0 & 0 & 0 & \\
\hline \multicolumn{6}{|l|}{ anxiety level } \\
\hline Normal & 75 & 92.6 & 70 & 94.6 & $0.005 * *$ \\
\hline Mild & 1 & 1.2 & 1 & 1.4 & \\
\hline Moderate & 5 & 6.2 & 3 & 4,1 & \\
\hline Severe & 0 & 0 & 0 & 0 & \\
\hline Very severe & 0 & 0 & 0 & 0 & \\
\hline \multicolumn{6}{|l|}{ Stress level } \\
\hline Normal & 80 & 98.8 & 71 & 95.9 & $0.846^{* *}$ \\
\hline Mild & 1 & 1.2 & 1 & 1.4 & \\
\hline Moderate & 0 & 0 & 2 & 2.7 & \\
\hline Severe & 0 & 0 & 0 & 0 & \\
\hline Very severe & 0 & 0 & 0 & 0 & \\
\hline
\end{tabular}

* independent $\mathrm{t}$-test

** chi- square

questionnaire were modified with estimation of household size in gram (Arisman, 2010) with table of food list that must filled by respondents. This questionnaire consists of 8 domain and 84 type of food. In this reseach, we calculated sodium level that containded in the foods. We use SQ-FFG from Shabrina (2017) which was valid and reliable
Global Physical Activity Questionnaire (GPAQ) is questionnaire for a physical activity data. This questionnaire was developed by WHO (2012) and was translated to Indonesian by Rahayu (2017). This instrument was valid and reliable. Information that will be obtained includes the physical activity of respondents in 3 domain and sedentary behavior, The domains consists of activity at work, travel 
activity (from place to places), and recreational activity. Analysis of the results of GPA questionnaire were classified based on the total MET minute/weeks. Physical activity were classified as heavy, moderate and mild intensity

Depression, Anxiety, Stress Scale 42 (DASS 42) was developed by Lovibond \& Lovibond (1995) and translated to Indonesia version by Adientya (2012 cit. Anggraini 2014) This instrument was valid and reliable and can be measure a state of depression, anxiety, and stress. The result were classified as mild, normal, moderate, severe and very severe.

This research is conducted after obtaining the Ethical clearance from the Ethics Commission of FKKMK UGM, number KE/ FK/0460/EC/2018. In its implementation, the researchers respect the research ethics including autonomy, beneficence, non-maleficence, confidentiality, and justice.

The result of data analysis conducted using chi-square test and independent t-test is to see whether there is a significant difference between sodium intake, physical activities and psychological problems of patients suffering from hypertension in rural and urban areas.

\section{RESULTS}

Most research respondents are women by $76.5 \%$ in rural areas and by $66.2 \%$ in urban areas with the average age of 57.8 years \pm 10.4 in rural areas and of $60.7 \pm 9.1$ in urban areas consisting of Javanese people (in rural areas $=100 \%$ while in urban areas $=97.3 \%$ ), Muslim (in rural areas $=96.3 \%$ and urban areas $78.4 \%$ ), average income is less than IDR900,000.00 (in rural areas $=80.3 \%$, in urban areas $=52.7 \%$ ). Respondents' education levels are various in both rural and urban areas starting from those without going to school until the higher education level. The respondents' occupations in both rural and urban areas are similarly various starting from housewives, private employees, entrepreneurs, labors, civil servants, retirees, and farmers. However, the occupation as farmers is not found in urban areas.
The result of research related to sodium intake, physical activities and psychological problems of patients suffering from hypertension in rural and urban areas is presented in Table 1.

Table 1 above shows that most patients suffering from hypertension in rural and urban areas have sufficient sodium intake $(<2000 \mathrm{mg})$. Based on the normality test using Mann-Whitney U Test, it is found that the sodium intake data in rural and urban areas has a normal distribution that the analysis to see the difference is conducted using the independent T-test. The obtained significance value is $0.669(\mathrm{p}>0.05)$ that it can be concluded there is no sodium intake difference of patients suffering from hypertension in both rural and urban areas.

The result of analysis conducted using GPAQ questionnaire is classified based on the total value of MET (Metabolic Equivalent) minute/week. The result shows that the average MET value of respondents in rural areas is $5845.33 \pm 5266.32$, while that in urban areas is $2847.29 \pm 3766.39$. The result of MET value in rural areas is $5845.33 \pm 5266.32$, while that in urban areas is $2847.29 \pm 3766.39$ MET. The physical activity level of respondents in rural areas is mostly classified into heavy category $(56.8 \%)$, while that in urban areas is classified into medium category (59.5\%). The obtained result of chi-square test is the value of $p<0.05$ indicating that there is a significant difference in physical activity level between those in rural and urban areas.

The psychological problems experienced by the respondents are measured using Depression, Anxiety, and Stress Scale (DASS 42). Based on the result of statistical analysis using Chi-square, the obtained significance value is 0.964 ( $p$ > 0.05 ) for depression, meaning that there is no depression level difference of patients suffering from hypertension in both rural and urban areas. For the anxiety level, the obtained significance value is 0.005 ( $p$ $<0.05$ ), meaning that there is anxiety level difference of patients suffering from hypertension in rural and urban areas. Meanwhile, for stress level, the obtained 
significant value is 0.846 ( $\mathrm{p}>0.05$ ), meaning that there is no stress level difference of patients suffering from hypertension in both rural and urban areas.

\section{DISCUSSIONS}

Table 1 above shows that most patients suffering from hypertension in both rural and urban areas have sufficient sodium intake $(<2000 \mathrm{mg})$. It is in accordance with the research conducted by Atmarita et al. (2016) that only $29.7 \%$ of Indonesian people have consumed salt more than that required by the body. It means that most Indonesian people still consume salt in normal range. This result is different from that obtained by Johnson, et al. (2017) that Indian people have higher salt consumption. The patients suffering from hypertension consuming sodium more than required by the body in both urban and rural areas needs to paid more attention as it may lead to further complications. WHO has recommended reducing sodium consumption as one activity to overcome the global crisis of non- transmitted disease and to reduce mortality caused by hypertension, cardiovascular disease and stroke (Ha, 2014). The absence of sodium intake difference and hypertension in urban areas is different from the results obtained by Yulia \& Rully (2015) that there is salt intake difference in urban and rural areas in Jatinangor, Sumedang.

The physical activities of patients suffering from hypertension in rural areas are classified into heavy category, while those in urban areas are classified into moderate category. The research conducted by Amu (2015) states that most patients suffering from hypertension in Indonesia have performed the physical activities as recommended (> $600 \mathrm{MET}$ ) at $86.47 \%$ in urban areas and $89.74 \%$ in rural areas. The result of chi-square test shows that the obtained value of $\mathrm{p}<0.05$ indicates that there is a significant difference of physical activity level in rural and urban areas. The result of this research is different from that conducted by Galav et al. (2015) stating that most patients suffering from hypertension in both rural and urban areas have sedentary life behavior. In the research conducted by Galav et al. (2015) the physical activities are only assessed based on the respondents' occupation types without considering those during the leisure time. most people in Rural areas perform the jobs classified into heavy level activity because employment in rural areas are in agricultural sectors (Galav et al, 2015; Thanh \& Duong, 2016). The research result shows that farmer is the second most occupation performed by the rural people after being the housewives $(28.4 \%)$. The heavy physical level activity in rural areas may be influenced by their activities in the daily performed agricultural and household working sectors. For example, even though the respondents are housewives, they sometimes go to the rice fields. More housewives in rural areas do heavy physical activities than those living in urban areas, consistent with the research conducted by Jayamani et al. (2013). In addition, the research result shows that the physical activities performed by the housewives in rural and urban areas are almost the same since the difference is only related to the required length of time to perform those activities. For example, if the respondents from urban areas sweep the yard take 10 minutes, the respondents from rural areas take 40 minutes as the yard size is different.

The patients suffering from hypertension in both urban and rural areas do not experience psychosocial problems, such as depression, anxiety, or stress. This result is different from that obtained by Kretchy, Owusu-Daaku \& Danquah (2014) from patients suffering from hypertension in Ghana. $56 \%$ respondents have experienced anxiety, 20\% experienced stress and $4 \%$ experienced depression. This is possibly due to the respondents who come from Javanese with its philosophy. The research conducted by Susetyo et al. (2014) shows that Javanese people view themselves as people who always prioritize togetherness and harmony, mutual cooperation, helping each other, living as the way it is, not too ambitious, having simple life, preferring to concede and prevent from any conflict as well as to avoid fights in their daily lives. This 
research has also found that Javanese people are easily to show their sympathy. Thus, Javanese people are helpful to the others who are in trouble and willingly visit their neighbors when they are sick. In their family relationship, Javanese people also always remember and help their old-age parents. Those Javanese personalities may support most patients suffering from hypertension in this research still have normal stress, depression and anxiety level although they have also experienced heavy pressures in their lives.

The data from respondents ware collected by recall, so may be the respondents can forgot about the data. Repsondents from rural area were comes from one village, that can be not representative for rural area.

\section{CONCLUSIONS}

It is concluded that there is a difference in physical activities and anxiety levels of patients suffering from hypertension in rural and urban areas. There is no difference between sodium intake, depression and stress level in patients suffering from hypertension in rural and urban areas.

For recommendation, the health workers should pay more attention to the ability of patients suffering from hypertension to manage their risk factors, such as diet (especially sodium consumption), physical activities, and also psychosocial problems. In addition, various activities and health education are greatly required to improve the patients' ability to manage their risk factors. This research may be continued by examining the factors influencing the ability of patients suffering from hypertension to manage their risk factors in both rural and urban areas.

\section{ACKNOWLEDGEMENT}

The researchers would like to express their gratitude to AINEC RESEARCH AWARD 2018 that has provided the financing grants for this research.

\section{REFERENCES}

Agrina., Rini, S.S., Hairitama, R. (2011). The adherence of older hypertension patient in hypertension diet . Study program of Nursing. Riau University.

Aisyiyah, F.N. (2009). Risk factors fo hypetension in four district/rural with highest prevalence in Java and Sumatra. Departemen Gizi Masyarakat Fakultas Ekologi Manusia Institut Pertanian Bogor. Departement of community nutrition, Faculty of Human Ecology. Bogor Agricultural Univestity.

Aizawa, T., Helble M. (2016). Urbanization and Inequality in Hypertension Diagnosis \& Medication in Indonesia. ADBI Working Paper 556: Tokyo. Asian Development Bank Institute.

Amu, D.A. (2015). Factors associated with to hypertension in urabn dan rural areas in Indonesia 2013. Under Graduate Thesis, Epidemiology Consentration, Study Program of Public health, Faculty of Medicine and Health Sciences, Universitas Islam Negeri Syarif Hidayatullah, Jakarta.

Anggraini, R (2014). The difference of stress level in coronary hearth disease patient and hypertension patient di Family docotr clinic Korpagama UGM. SStudy program of NUrsing. Faculty of Medicine, Universitas Gadjah Mada

Arisman (2010). Nutrition SCience textbook: Nutrition in the life cycle. Jakarta: EGC.

Atmarita, A, Jahari, A.B., Sudikno, S., \& Soekatri, M. (2016). Intake of sugar, salt and fat in Indonesia: Analysys of 2014 individual food consumtion surveys (SKMI). Journal of Indonesian Nutrition Assosiation. 39 (1), 1-14

Furkaniaty, A. (2009). The correlation of sodium intake with hypertension in coronary hearth disease patient in Cardiology outpatient RSUP Dr. 
Sardjito Yogyakarta. Health Nutrition Study Program. Universitas Gadjah Mada.

Galav, A., Bhatanagar, R., Meghwal, S.C., Jain, M. (2015). Prevalence of hypertension among rural and urban population in southren rajasthan. National Journal of Community Medicine, 6(2), 174178. Retrieved from www.njemindia.org.

Ha, SK. (2014). Dietary Salt intake and hypertension. Electrolyte Blood Press 12, 7-18

Indonesian Cardiovascular Specialist Association (PERKI). (2015). Guidelines for managing hypertension in Cardiovascular diseases. Retrieved from http://www.inaheart.org/upload/file /Pedoman_TataLaksna_hipertensi pada_penyakit_Kardiovaskular_20 $15 . \mathrm{pdf}$

Islamia, I.' Sunasti, E., \& Hernawati, N (2012). Social pressure, psycological pressure and family welfare in rural and urban areas. Under graduate thessis. Bogor Agiculture institute. Retrieved from http://repository.ipb.ac.id/handle/12 3456789/60805

Jayamani, V., Gopichandran, V., Lee, P., Alexander, G., Christopher, S., Prasad, J.H. 2013. Diet and physical activity among women in urban and rural areas in south india: a community based comparative survey. J Family Med Prim Care, 2(4), 334-338. doi: 10.4103/22494863.123782.

Johnson, C., I (2017). Mean dietary salt intake in Urban and rural areas in India: A Population survey of 1395 persons. J.Am heart assoc. DOI: 10.1161/JAHA.116.004547, 1-8

Khusun, H., Wiradnyani, L.A.A., Siagian, N. (2016). Factors associated with obesity in adultd in urban Indonesia. Penelitian Gizi dan Makanan, 38(2), 95-110. doi: 10.22435/pgm.v38i2.5539.95-110.

Kretchy, A.A., Owusu-Daaku, F.T., Danquah, S.A. (2014). Mental health in hypertension: assessing symptoms of anxiety, depression and stressonanti-hypertensive medication adherence. Int $J$ Ment Health syst, 21, 8-25.

Kumar, K., Kothari, R.P., Kothari, K., Garg, S., Khandelwal, M.K., Gupta, R. (2013). Prevalence of Hypertension in an Urban and Rural Area of Jaipur District. International J. of Healthcare \& Biomedical Research. 1(3): 120126.

Lovibond, P.F. \& Lovibond, S.H. (1995). The structure of negative emotional states: comparison of Depression Ansiety Stress Scale (DASS) with the Beck Depression and anxiety inventories. Behav. Res. Ther. 33: 335-343.

Milis, K.T.; Bundy, J.D.; Kelly T.N.; Reed, J.E. Kearney, P.M.; Reynolds, K, Chen, J.; \& He, J. (2016). Global Disparities of Hypertension prevalence and control: Asystematic analysis of Populationbased STudies from 90 countries. Circulation. 134(6): 441-450. doi: 10.1161/CIRCULATIONAHA .115 .018912

Ministry of Health of the Republic of Indonesia. (2013). Basic Health Research (Riskesdas), Retrieved from dari

www.depkes.go.id/resources/downl oad/general/Hasil\%20Riskesdas\%202013.p df

Ministry of Health of the Republic of Indonesia. (2014). Hypertension. Jakarta: Indonesian Ministry of Health's Data and Information Center.

Primadita, A. (2009). The correlation of sodium, potassium, calcium and magnesium intake with hypertension in Mergangsan Health Center, Yogyakarta. Health Study Program. Universitas Gadjah Mada.

Rahayu, S. (2017). The effect of audiovisual health education on the level or physical activity in population with have risk of 
metabolic syndrome in Turi Health Care Center, Sleman. Undergraduate thesis, School of Nursing. Faculty of Medicine. Gadjah Mada, Yogyakarta.

Shabrina, K.N. (2017). The effect of audiovisual health education to sodium intake in in population with have risk of metabolic syndrome in Turi Health Care Center, Sleman. Undergraduate thesis, School of Nursing. Faculty of Medicine. Gadjah Mada, Yogyakarta.

Susetyo, D.P.B., Widiyatmadi, H.M.E., Sudiantara, Y. (2014). Self-concept and self-appreciation of the Javenese. Psikodimensia, 13(1): 4759. Retrieved from i: http://journal.unika.ac.id/index.php/ psi/article/view/277/268

Thanh, V.T., Duong, N.A., (2016).
Promoting rural development, employment, and inclusive growth in ASEAN. Economic Research Institute for ASEAN (ERIA) Discussion Paper Series.

World Health Organization. 2012. Global physical activity questionnaire (GPAQ). WHO: Geneva, Switzerland.

Xue, J., Chen, S., Bogner, H.R., Tang, W., Li, L., Conwell, Y. 2016. The prevalence of depressive symptoms among older patients with hypertension in rural China. International Journal of Geriartric Psychiatry, 32 (12), 1411-1417. doi: 10.1002/gps.4628.

Yulia, S., \& Rully, R. ( 2015). Salt intake in urban and rural community in Jatinangor, Sumedang. Journal of hypertension.

33. 